\title{
Biocontrol Efficacy of Antagonist Yeasts to Gray Mold and Blue Mold on Apples and Pears in Controlled Atmospheres
}

\author{
Shiping Tian, Qing Fan, Yong Xu, and Haibo Liu, Institute of Botany, Chinese Academy of Sciences, Beijing \\ 100093 P.R. China
}

\begin{abstract}
Tian, S. P., Fan, Q., Xu, Y., and Liu, H. B. 2002. Biocontrol efficacy of antagonist yeasts to gray mold and blue mold on apples and pears in controlled atmospheres. Plant Dis. 86:848-853.

Biocontrol capability of the yeasts Trichosporon sp. and Cryptococcus albidus against Botrytis cinerea and Penicillium expansum was evaluated in apple (cv. Golden Delicious) and pear (cv. Jingbai) fruits at $1{ }^{\circ} \mathrm{C}$ in air and under controlled atmospheres (CA) with $3 \% \mathrm{O}_{2}+3 \% \mathrm{CO}_{2}$ or $3 \% \mathrm{O}_{2}+8 \% \mathrm{CO}_{2}$. Trichosporon sp. controlled gray mold and blue mold of apple fruits more effectively than $C$. albidus $(P<0.05)$. Apple fruits treated with Trichosporon sp. and $C$. albidus had a lower incidence of gray mold rot than blue mold rot in the same storage conditions. Biocontrol efficacy of the yeasts for controlling gray mold and blue mold was better in apples than in pears. Populations of the yeasts in drop-inoculated wounds in fruits increased rapidly after 20 days at $1^{\circ} \mathrm{C}$ both in air and in $\mathrm{CA}$ conditions. There was no significant difference in colony diameters of the two pathogens cultured in 0 to $15 \% \mathrm{CO}_{2}$ concentrations after 7 days at $20^{\circ} \mathrm{C}$, but the colony diameter of both $B$. cinerea and $P$. expansum at $20 \% \mathrm{CO}_{2}$ was significantly less than in other treatments $(P<0.05)$. CA with $3 \% \mathrm{O}_{2}+8 \% \mathrm{CO}_{2}$ inhibited the pathogenic fungi more than CA with $3 \% \mathrm{O}_{2}+3 \% \mathrm{CO}_{2}$.
\end{abstract}

Additional keywords: Malus, postharvest disease, Pyrus

Postharvest diseases caused by pathogenic fungi result in great losses in fruits and vegetables (27). Application of synthetic fungicides is generally the main method to control postharvest diseases, but public concern over food safety and the development of fungicide resistance by pathogens has increased the search for alternative means potentially less harmful to human health and the environment $(9,15,33)$. Biological control has been advanced as an alternative to synthetic fungicides, and considerable success has been achieved by utilizing antagonistic microorganisms $(17,20,36)$. Some yeasts and bacteria have been reported to effectively reduce various postharvest diseases of fruits $(3,12,18)$. However, previous research often focused on isolation and selection of antagonists $(13,19,25)$ and comparing their biocontrol effectiveness for control of postharvest diseases $(20,21)$. In addition, attempts were made to enhance efficacy by adding calcium, carbohydrates, amino acids, and other nitrogen compounds $(7,8,14)$, or by combining antagonists with fungicides $(4,5,10,28,34)$. There is little information about biocontrol efficacy of antagonists in low temperatures

Corresponding author: S. P. Tian

E-mail: shiping@95777.com

Accepted for publication 20 March 2002.

Publication no. D-2002-0528-04R

(C) 2002 The American Phytopathological Society and under controlled atmosphere (CA) storage, except that Chand-Goyal and Spotts (6) reported biological control of postharvest diseases of apple and pear under semi-commercial and commercial conditions using three saprophytic yeasts. Recently, we isolated Trichosporon sp. and Cryptococcus albidus from peach fruits (Prunus persica) and found them to be very effective for control of gray mold and blue mold of apple fruits at $20^{\circ} \mathrm{C}(11,34)$. Many postharvest pathogenic fungi grow at $-4^{\circ} \mathrm{C}(1,31)$ and cause decay of fruits and vegetables below $-2^{\circ} \mathrm{C}(2,30,32)$. CA storage is considered to be effective for reducing fruit decay $(24,35)$. CA with $\mathrm{CO}_{2}$ concentrations above $2.8 \%$ effectively reduced the development of lesions incited by $B$. cinerea and $P$. expansum in apple fruits (26). Therefore, it is necessary to study the effect of low temperature and CA conditions on the activity of antagonists and their biocontrol capacity to pathogenic fungi causing postharvest decay of fruits. Successful commercial use of biocontrol of postharvest decay of fruits and vegetables will depend on the adaptability of antagonists to commercial low-temperature and CA conditions.

The objectives of this study were: (i) to determine population dynamics of Trichosporon sp. and C. albidus in wounds of fruits kept at $25^{\circ} \mathrm{C}$ or in cold storage and $\mathrm{CA}$ at $1{ }^{\circ} \mathrm{C}$; (ii) to compare the biocontrol efficacy of the yeasts to gray mold and blue mold on apple and pear fruits in CA with $3 \% \mathrm{O}_{2}+3 \% \mathrm{CO}_{2}$ or $3 \% \mathrm{O}_{2}+8 \% \mathrm{CO}_{2}$ at $1{ }^{\circ} \mathrm{C}$; and (iii) to investigate growth of $B$. cinerea and $P$. expansum in $\mathrm{CA}$ with different $\mathrm{CO}_{2}$ concentrations at 20 and $1{ }^{\circ} \mathrm{C}$.

\section{MATERIAL AND METHODS}

Pathogen inoculum. B. cinerea and $P$. expansum were isolated from naturally infected apple fruit and cultured on oatmeal agar (OMA) (oatmeal $60 \mathrm{~g}$, sucrose $30 \mathrm{~g}, \mathrm{NaNO}_{3} 10 \mathrm{~g}$, agar $12 \mathrm{~g} /$ liter) and potato dextrose agar (PDA), respectively, at $25^{\circ} \mathrm{C}$ for 2 weeks. Conidial suspensions were prepared by flooding the cultures with sterile distilled water containing $0.05 \%$ ( vol/vol) Tween 80 . The conidial concentrations of the pathogens were determined with the aid of a hemacytometer and adjusted to $5 \times 10^{4}$ spores per $\mathrm{ml}$.

Antagonist. The yeast antagonists were isolated from peach fruits according to the method of Wilson et al. (37) and identified as Cryptococcus albidus (Saito) Skinner and Trichosporon sp. by CABI Bioscience Identification Services (IMI 382212; 382211). The yeasts were cultured in 250$\mathrm{ml}$ Erlenmeyer flasks with $50 \mathrm{ml}$ of nutrient yeast dextrose broth (NYDB: $8 \mathrm{~g}$ of nutrient broth, $5 \mathrm{~g}$ of yeast extract, and 10 $\mathrm{g}$ of dextrose in 1 liter of water) on a rotary shaker at $200 \mathrm{rpm}$ for $24 \mathrm{~h}$ at $28^{\circ} \mathrm{C}$. The yeast cells were harvested by centrifugation at $6,000 \mathrm{rpm}$ (about $2,500 \times g$ ) for 10 min, washed twice with $0.05 \mathrm{M}$ phosphate buffer at $\mathrm{pH} 7.0$, and resuspended in distilled water. The concentrations of cells of both yeasts in the suspensions were adjusted to $1 \times 10^{6}$ and $5 \times 10^{6} \mathrm{CFU} / \mathrm{ml}$, respectively, with the aid of a hemacytometer.

Apple and pear fruits. 'Golden Delicious' apple (Malus domestica Borkh.) and 'Jingbai' pears (Pyrus ussuriensis Maxim.) were used in this study. The fruits were harvested from an orchard at the Institute of Forest and Fruits, Beijing Academy of Agricultural Sciences, and immediately transported to the laboratory after harvest. The firmness of the apples and pears was 32.3 and $49.9 \mathrm{~N}$ as determined by a penetrometer (FT-327, UC Fruit Firmness Tester, Milano, Italy), and total soluble solids were 12.9 and $13.8 \%$, respectively. Apple and pear fruits were washed with $2 \%$ sodium hypochlorite for $2 \mathrm{~min}$, rinsed with tap water, and air-dried before wounding.

Biocontrol efficacy of yeasts in different storage conditions. A uniform wound, $3 \mathrm{~mm}$ deep and $3 \mathrm{~mm}$ wide, was made at the equator of each fruit (put on its side) using the tip of sterile dissecting needle. 
Aliquots of $20 \mu \mathrm{l}$ of $1 \times 10^{6} \mathrm{CFU} / \mathrm{ml}$ suspension of each yeast and sterile distilled water (control) were pipetted into each wound site. After $4 \mathrm{~h}, 20 \mu \mathrm{l}$ of a suspension of $B$. cinerea or $P$. expansum $\left(5 \times 10^{4}\right.$ spores per $\mathrm{ml}$ ) was placed in each wound, and fruits dried in air at room temperature for $4 \mathrm{~h}$. Fruits were placed in a plastic tray $(400 \times 300 \times 100 \mathrm{~mm})$ and transferred to a controlled atmosphere cabinet (Fruit s.r.l. Control, type FC-701, Milano, Italy) with $3 \% \mathrm{O}_{2}+3 \% \mathrm{CO}_{2}$ or $3 \% \mathrm{O}_{2}+8 \% \mathrm{CO}_{2}$ at $1{ }^{\circ} \mathrm{C}(\mathrm{RH}>95 \%)$. There were three replicate trials of 10 fruits per treatment with a complete randomization of trays in each test. The same trays wrapped with highdensity polyethylene sleeves to keep high humidity (about $95 \%$ ) were stored in air at $1{ }^{\circ} \mathrm{C}$ as the control. The test was conducted twice. Disease incidence and lesion size in the fruits were measured every 20 days of storage. Two diameters were measured at right angles across each lesion on the surface of infected fruit. Data presented are the means of lesion diameters. The fruits both in air and under CA conditions were stored for 60 days.

Population dynamics of yeasts in different storage conditions. Three wounds per fruit were made equidistant around the stem, and then $20 \mu \mathrm{l}$ of each yeast suspension $\left(5 \times 10^{6} \mathrm{CFU} / \mathrm{ml}\right)$ was applied to each wound site. The fruits were stored in different conditions: (i) in air at $25^{\circ} \mathrm{C}$, and populations were determined daily for 8 days; and (ii) in air and $\mathrm{CA} 3 \% \mathrm{O}_{2}+3 \%$ $\mathrm{CO}_{2}$ or $3 \% \mathrm{O}_{2}+8 \% \mathrm{CO}_{2}$ at $1{ }^{\circ} \mathrm{C}$, and fruit samples were taken to determine antago- nist populations $1 \mathrm{~h}$ after inoculation and after 20, 40, and 60 days of storage. The yeasts were recovered as described by Janisiewicz (16) by removing the wound tissue with a cork borer. The resulting cylinder $(1 \mathrm{~cm}$ diameter $\times 1 \mathrm{~cm}$ deep) was placed in a mortar with $1 \mathrm{ml}$ of $0.05 \mathrm{M}$ phosphate buffer at $\mathrm{pH} 7.0$ and was ground with a pestle. Serial 10 -fold dilutions were made in phosphate buffer, and $100 \mu \mathrm{l}$ of each dilution was plated on nutrient yeast dextrose agar (NYDA) medium (10 dishes). The colony counts were expressed as the $\log _{10}$-transformed numbers of cells per wound. An analysis of variance of the $\log _{10}$-transformed data was carried out for each sampling date. There were three replications of each treatment, and the experiment was conducted twice.

Pathogen growth in vitro under different storage conditions. A 50- $\mu$ l aliquot of suspensions of $B$. cinerea and $P$. expansum $\left(5 \times 10^{4}\right.$ spores per $\left.\mathrm{ml}\right)$ was placed into a hole $(6 \mathrm{~mm})$ in the center of each dish (60 mm diameter) containing $10 \mathrm{ml}$ of OMA or PDA, respectively. There were two tests in this experiment. In the first test, dishes were placed in cabinets and ventilated with a continuous flow of air or different $\mathrm{CO}_{2}$ concentrations. The high $\mathrm{CO}_{2}$ atmosphere was established with a flow-through system by mixing $\mathrm{N}_{2}$ and $\mathrm{CO}_{2}$. The concentrations were $0,3,8,15$, and $20 \%( \pm 0.5 \%)$ for $\mathrm{CO}_{2}$, and $21,20.7$, 19,17 , and $15 \%( \pm 0.5 \%)$ for $\mathrm{O}_{2}$, measured with a gas analyzer (Fruit s.r.l. Control, type FC-701, Milano, Italy) daily. The cabinets were kept at $20^{\circ} \mathrm{C}$ for 7 days. In the second test, dishes were kept in ventilation storage and in CA cabinets with $3 \%$ $\mathrm{O}_{2}+3 \% \mathrm{CO}_{2}$ or $3 \% \mathrm{O}_{2}+8 \% \mathrm{CO}_{2}$ at $1{ }^{\circ} \mathrm{C}$ for 40 days. The colony diameters of the fungi were measured at the end of the storage period. There were 10 dishes in each treatment and the treatments were replicated three times. The test was conducted twice.

Statistical analysis. All statistical analyses were performed with SAS version 6.12 (SAS Institute, Cary, NC). The data were analyzed by one-way analysis of variance (ANOVA). Means were separated with the Student-Newman-Keuls test.

\section{RESULTS}

Efficacy of antagonists for controlling gray mold and blue mold rots in different storage conditions. The antagonists Trichosporon sp. and C. albidus were more effective for control of apple decay in CA with low $\mathrm{O}_{2}$ and high $\mathrm{CO}_{2}$ than in air, according to the results of two experiments (Figs. 1 and 2). Trichosporon sp. was more effective than $C$. albidus $(P<0.01)$ in the same storage conditions. Gray mold rot in apple fruits treated with $C$. albidus reached $40 \%$ and $10 \%$ incidence after 40 days in air storage and CA, respectively, but no disease was found in apples treated with Trichosporon sp. in the same storage conditions. However, blue mold rot in apples treated with the yeasts showed relatively higher decay incidence compared with gray mold rot in the same storage conditions. The similar results obtained in repeated experiments demonstrated that biocontrol efficacy of Trichosporon sp. and $C$.

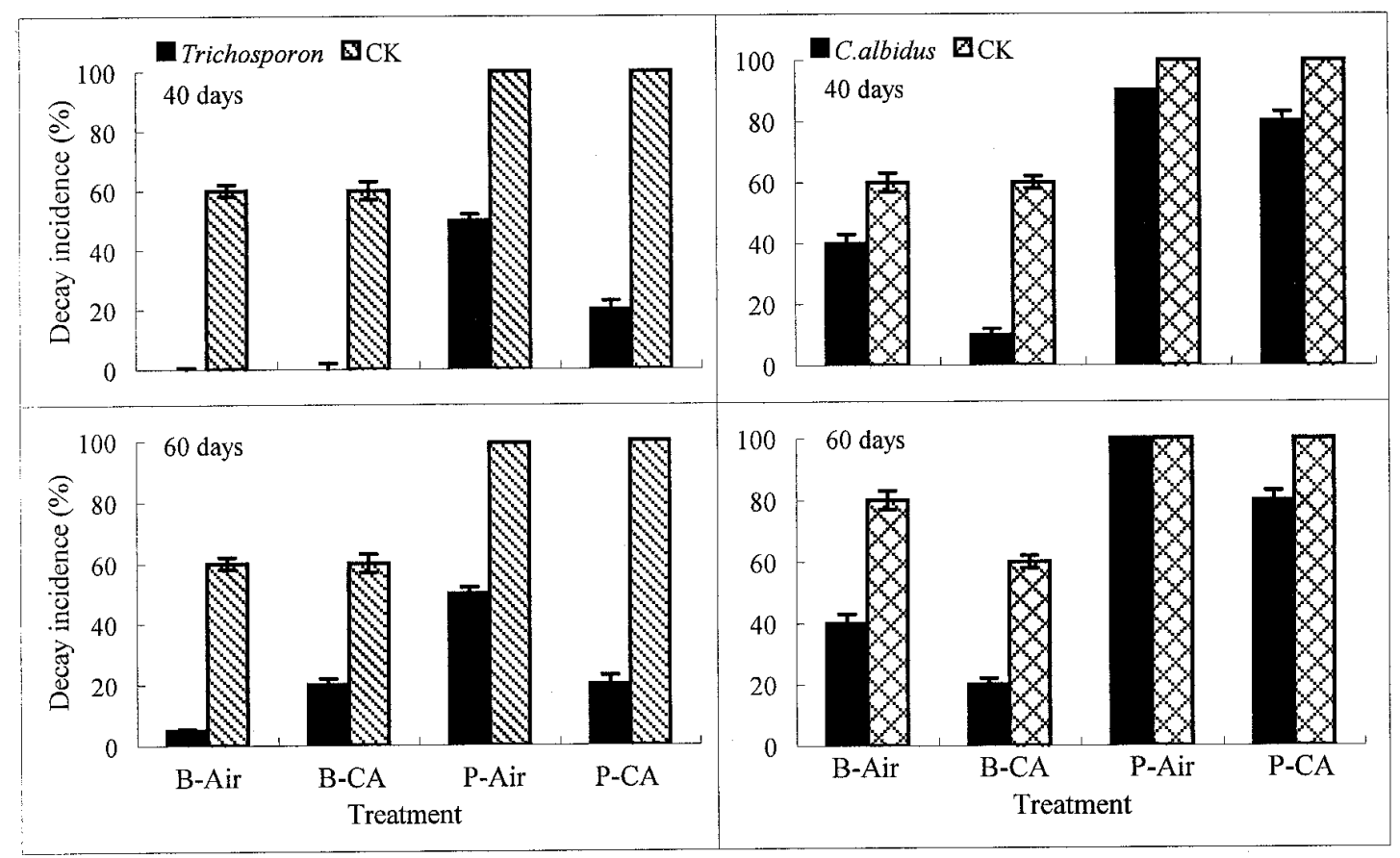

Fig. 1. Incidence of gray mold and blue mold decay in apple fruits treated with Trichosporon sp. and Cryptococcus albidus in air and controlled atmosphere (CA) with $3 \% \mathrm{O}_{2}+3 \% \mathrm{CO}_{2}$ at $1{ }^{\circ} \mathrm{C}$. Concentration of the yeasts was $1 \times 10^{6} \mathrm{CFU} / \mathrm{ml}$. There were 10 fruits with three replicates in each treatment and the test was conducted twice. The data were pooled from two experiments. Bars represent standard errors of the mean. $\mathrm{CK}=$ nontreated control; $\mathrm{B}=$ Botrytis cinerea $\mathrm{P}=$ Penicillium expansum. 
albidus for control of gray mold and blue mold in apples (Figs. 1 and 2) was better than that in pears (Figs. 3 and 4). There was no significant CA effect on incidence of gray mold and blue mold rots in control fruits (of both apple and pear) stored for 40 and 60 days. Lesions enlarged as storage time increased. Again, the two antagonists provided better control of gray mold than of blue mold in apple fruits (Figs. 1 and 2).

Effects of storage conditions on population dynamics of the yeasts. Trichosporon sp. and $C$. albidus multiplied rapidly in fruit wounds after 1 day at $25^{\circ} \mathrm{C}$
(Fig. 5). At the beginning of the experiment, population of the yeasts was $1.2 \times$ $10^{4}$ to $1.5 \times 10^{4} \mathrm{CFU}$ per wound. Within $24 \mathrm{~h}$, the population size of Trichosporon sp. and C. albidus increased more than 30 fold in apples and 20 -fold in pears at $25^{\circ} \mathrm{C}$, then stabilized at the same density $(4.58 \times$

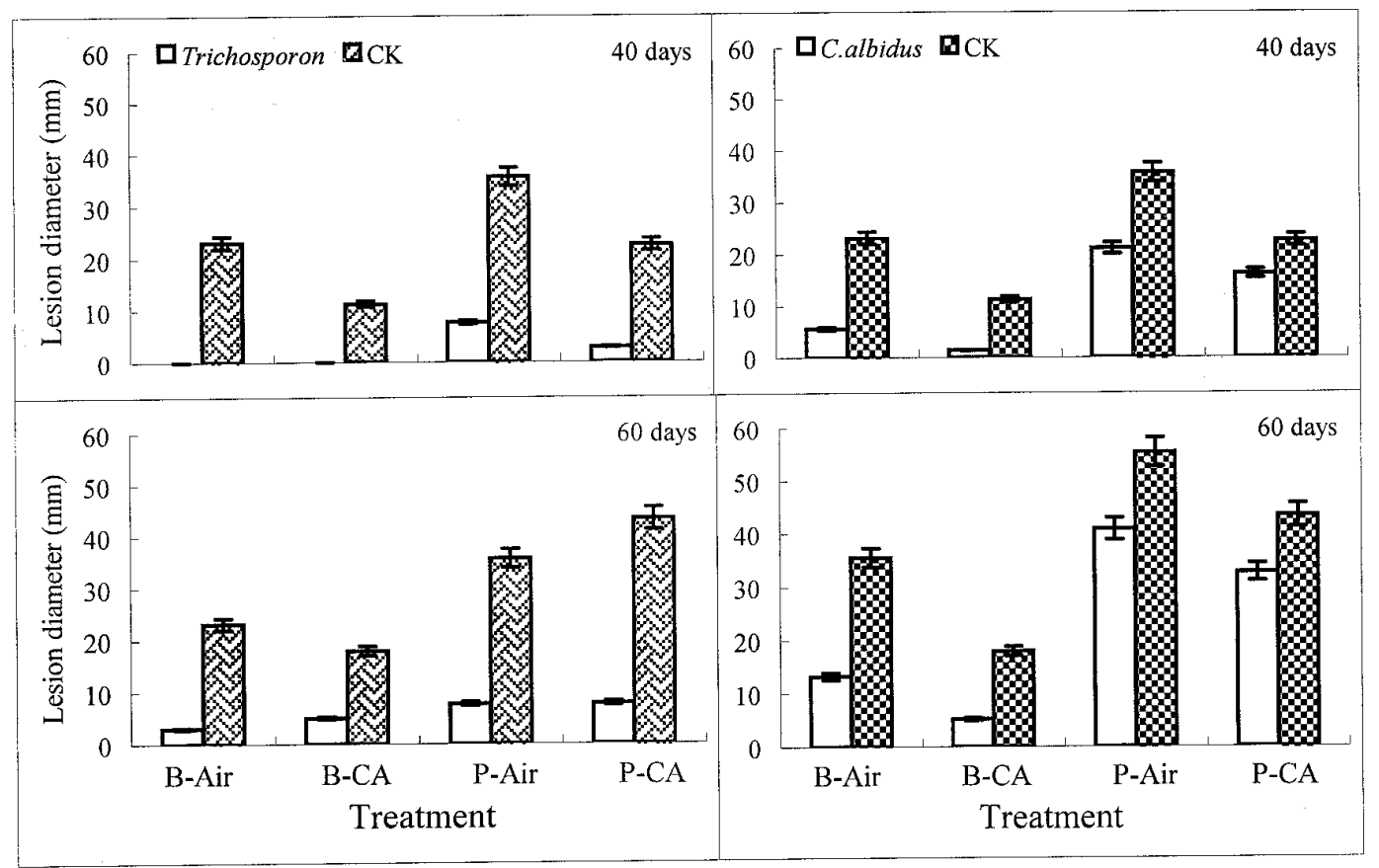

Fig. 2. Diameters of gray mold and blue mold lesions in apple fruits treated with Trichosporon sp. and Cryptococcus albidus in air and in controlled atmosphere (CA) with $3 \% \mathrm{O}_{2}+3 \% \mathrm{CO}_{2}$ at $1^{\circ} \mathrm{C}$. Concentration of the yeasts was $1 \times 10^{6} \mathrm{CFU} / \mathrm{ml}$. There were 10 fruits with three replicates in each treatment and the test was conducted twice. The data were pooled from two experiments. Bars represent standard errors of the mean. $\mathrm{CK}=$ nontreated control; $\mathrm{B}=$ Botrytis cinerea $; \mathrm{P}=$ Penicillium expansum .

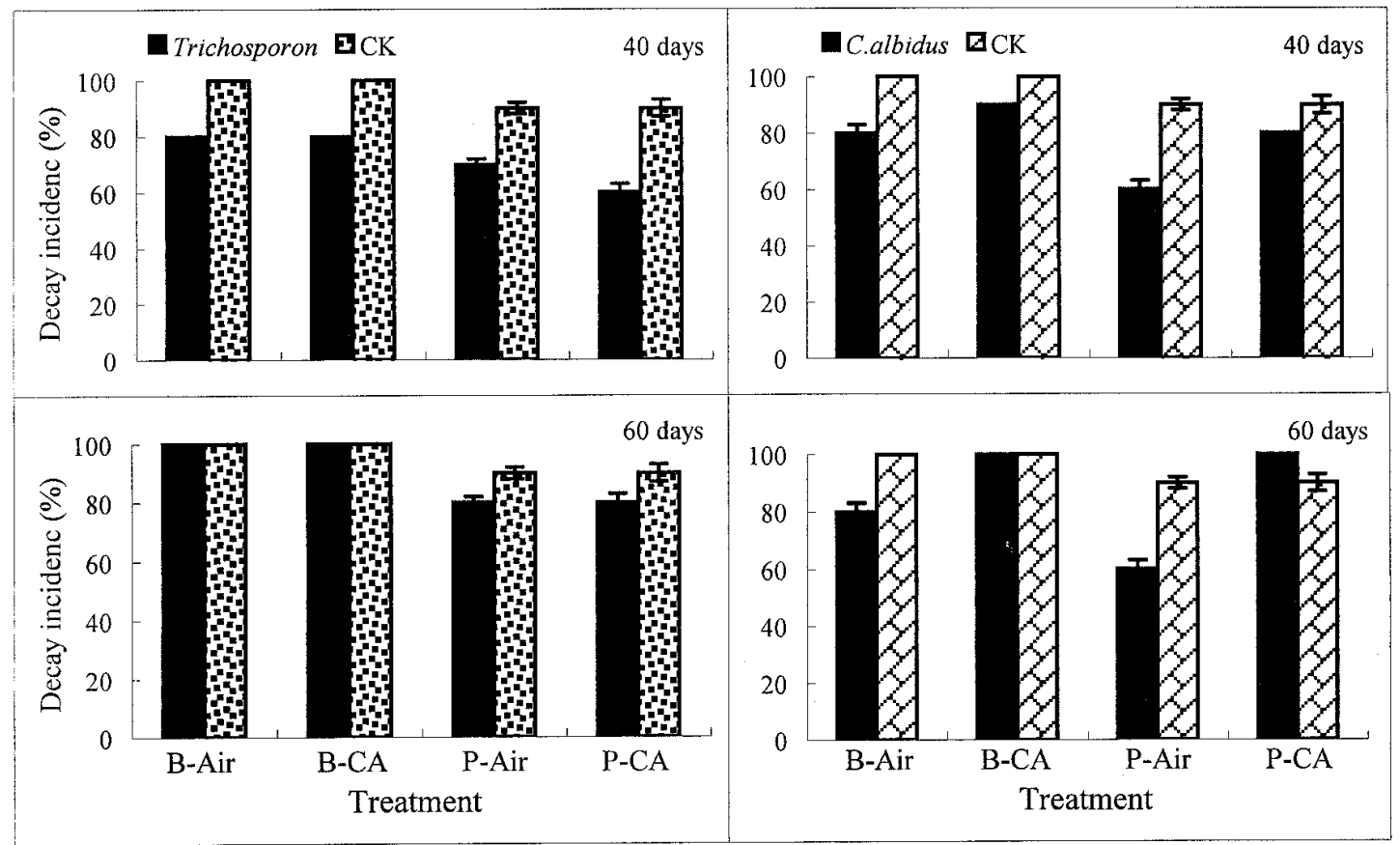

Fig. 3. Incidence of gray mold and blue mold decay in pear fruits treated with Trichosporon sp. and Cryptococcus albidus in air and in controlled atmosphere (CA) with $3 \% \mathrm{O}_{2}+3 \% \mathrm{CO}_{2}$ at $1{ }^{\circ} \mathrm{C}$. Concentration of the yeasts was $1 \times 10^{6} \mathrm{CFU} / \mathrm{ml}$. There were 10 fruits with three replicates in each treatment and the test was conducted twice. The data were pooled from two experiments. Bars represent standard errors of the mean. $\mathrm{CK}=$ nontreated control; $\mathrm{B}=$ Botrytis cinerea $; \mathrm{P}=$ Penicillium expansum. 
$10^{5}$ to $1.50 \times 10^{6} \mathrm{CFU}$ per wound), except Trichosporon sp. in pear, which fluctuated and reached a maximum value of $5.1 \times 10^{6}$ CFU per wound after 5 days (Fig. 5).

Based on results from two experiments, low temperature and CA conditions did not significantly affect populations of the yeasts in wounds (Fig. 6). Populations of Trichosporon sp. and C. albidus in fruit wounds increased rapidly in the first 20 days of storage at $1{ }^{\circ} \mathrm{C}$ both in air and in $\mathrm{CA}$ at $3 \% \mathrm{O}_{2}+3 \% \mathrm{CO}_{2}$ and $3 \% \mathrm{O}_{2}+8 \%$ $\mathrm{CO}_{2}$. Even after 60 days, the populations of Trichosporon sp. and $C$. albidus in fruit wounds remained $6.1 \times 10^{4}$ to $5.45 \times 10^{5}$ CFU per wound in air and $4.33 \times 10^{4}$ to $2.52 \times 10^{5} \mathrm{CFU}$ per wound in CA conditions. The highest populations of Trichosporon sp. were $5.45 \times 10^{5}, 2.60 \times 10^{5}$, and $2.89 \times 10^{5} \mathrm{CFU}$ per wound in pear fruits after 40 days in air, $3 \% \mathrm{O}_{2}+3 \% \mathrm{CO}_{2}$, and $3 \% \mathrm{O}_{2}+8 \% \mathrm{CO}_{2}$, respectively, which were 43.6, 20.8, and 23.1 times the initial populations (Fig. 6). C. albidus reached the highest populations of $8.28 \times 10^{5}, 3.3 \times 10^{5}$, and $5.72 \times 10^{5} \mathrm{CFU}$ per wound after 60 days in apples kept in air, 40 days in apples stored in $3 \% \mathrm{O}_{2}+3 \% \mathrm{CO}_{2}$, and 20 days in pears stored in $3 \% \mathrm{O}_{2}+8 \% \mathrm{CO}_{2}$, respectively. These populations increased $66.2,26.4$, and 45.8 times the initial populations.

Effects of storage conditions on pathogen growth in vitro. The concentration of $\mathrm{CO}_{2}$ affected growth of $B$. cinerea and $P$. expansum in vitro (Fig. 7). There was no difference in colony diameters of the pathogens cultured in 0 to $15 \% \mathrm{CO}_{2}$ after 7 days at $20^{\circ} \mathrm{C}$, but the colony diame- ter both of $B$. cinerea and of $P$. expansum at $20 \% \mathrm{CO}_{2}$ was significantly smaller than in other treatments $(P<0.01)$. Colony diameters of $B$. cinerea and $P$. expansum kept at $20 \% \mathrm{CO}_{2}$ were 40 and $16 \mathrm{~mm}$, respectively, which were only 66.7 and $57 \%$ of the control treatment $\left(21 \% \mathrm{O}_{2}+\right.$ $\left.0 \% \quad \mathrm{CO}_{2}\right)$. In addition, $B$. cinerea grew more rapidly than $P$. expansum in the same treatments $(P<0.01)$. There was no sig-

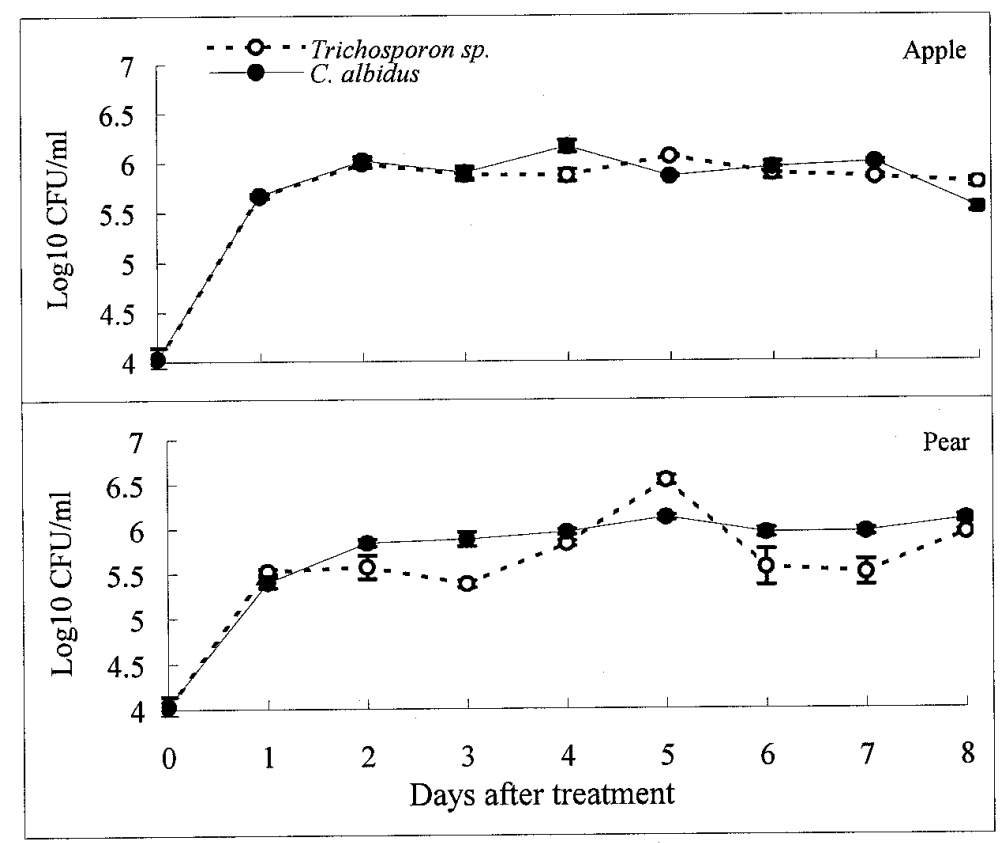

Fig. 5. Population dynamics of Cryptococcus albidus and Trichosporon sp. in wounds of apple and pear fruits incubated at $25^{\circ} \mathrm{C}$ in air. Fruits were wounded and $20 \mu \mathrm{l}$ of suspension at $5 \times 10^{6} \mathrm{CFU} / \mathrm{ml}$ was applied to each wound. The antagonists were recovered by removing the wounded tissue, grinding it in a mortar with $0.05 \mathrm{M}$ phosphate buffer, and plating $0.1 \mathrm{ml}$ of a 10-fold dilution on nutrient yeast dextrose agar (NYDA). There were three replicates of one fruit each per treatment and the data were pooled from two experiments. Bars represent standard errors of the mean.

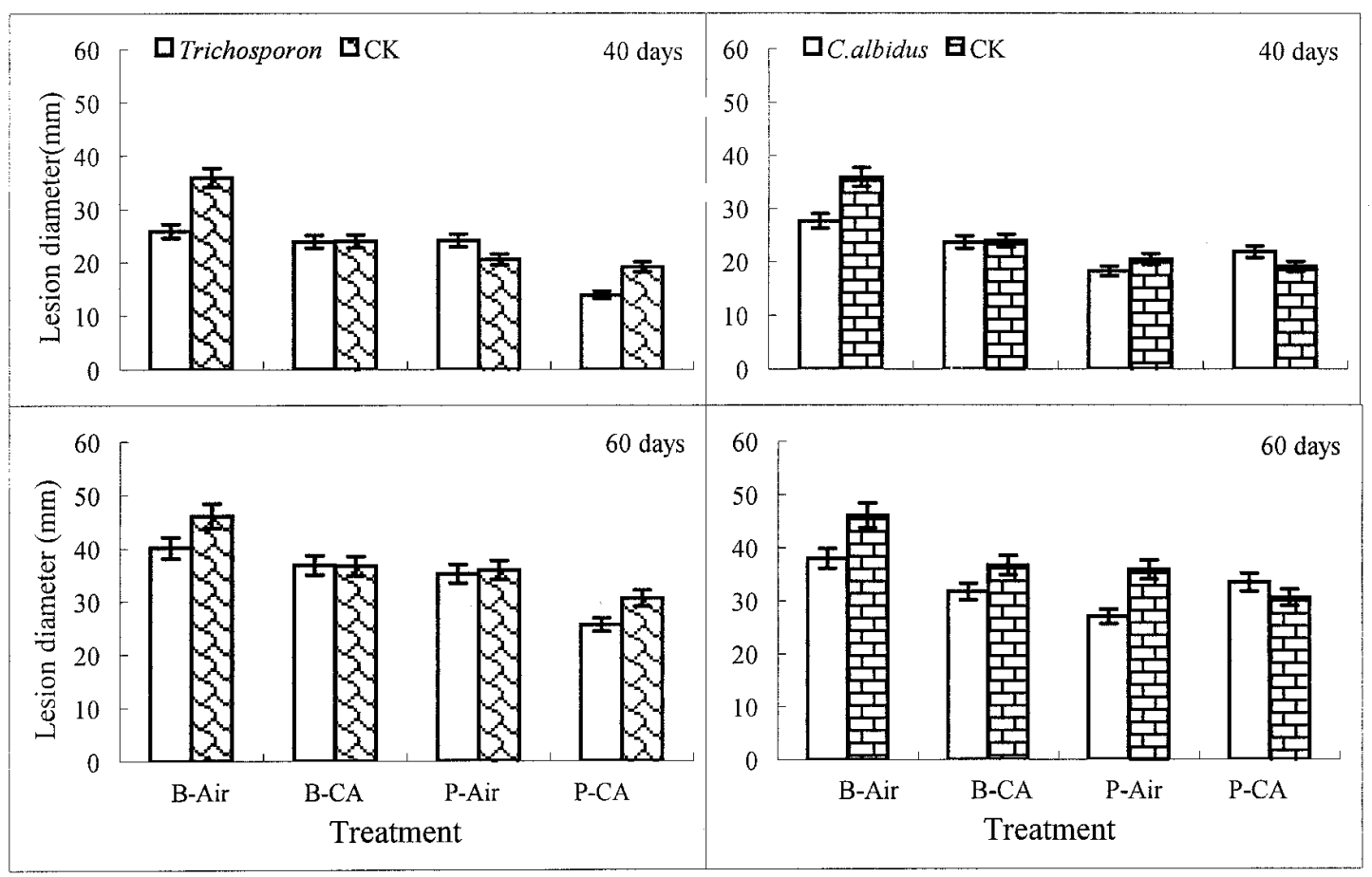

Fig. 4. Diameters of gray mold and blue mold lesions in pear fruits treated with Trichosporon sp. and Cryptococcus albidus in air and in controlled atmosphere (CA) with $3 \% \mathrm{O}_{2}+3 \% \mathrm{CO}_{2}$ at $1^{\circ} \mathrm{C}$. Concentration of the yeasts was $1 \times 10^{6} \mathrm{CFU} / \mathrm{ml}$. There were 10 fruits with three replicates in each treatment and the test was conducted twice. The data were pooled from two experiments. Bars represent standard errors of the mean. $\mathrm{CK}=$ nontreated control; $\mathrm{B}=$ Botrytis cinerea $; \mathrm{P}=$ Penicillium expansum. 
nificant difference in the data obtained in repeated experiments.

Low temperature and CA conditions also influenced pathogen growth (Fig. 7). However, effects of CA on growth of $B$. cinerea and $P$. expansum were greater than low temperature alone $(P<0.01)$. CA with the higher $\mathrm{CO}_{2}$ concentration $\left(3 \% \mathrm{O}_{2}+8 \%\right.$ $\mathrm{CO}_{2}$ ) inhibited growth of both fungi more than $\mathrm{CA}$ with lower $\mathrm{CO}_{2}$ concentration $\left(3 \% \mathrm{O}_{2}+3 \% \mathrm{CO}_{2}\right)$.

\section{DISCUSSION}

Controlled atmosphere with high $\mathrm{CO}_{2}$ and low $\mathrm{O}_{2}$ concentrations has been widely used in commercial storage for reducing decay, delaying senescence, and maintaining quality of fruits and vegetables. In general, pathogenic fungi are suppressed by low temperature and $\mathrm{CA}$ with high $\mathrm{CO}_{2}$ and low $\mathrm{O}_{2}(28,30)$, but many studies show that Botrytis spp. and Penicillium spp. can grow and cause decay in fruits and vegetables even at -2 and $-4^{\circ} \mathrm{C}(1,2,29,31)$. Therefore, the ability of antagonists to grow at low temperature and CA conditions will affect their control of postharvest diseases. The results of two experiments demonstrated that the application of $C$. albidus and Trichosporon sp. resulted in better control of gray mold and blue mold rots in apples compared with pears both in air and under CA conditions at $1{ }^{\circ} \mathrm{C}$ (Figs. 1 and 3 ), which indicated there were differences in biocontrol efficacy of yeast to the same disease in different hosts.

Many yeasts require $\mathrm{CO}_{2}$ as a carbon source for growth, and about $10 \% \mathrm{CO}_{2}$ enhances sporulation in yeast fungi (28). Miller and Sugar (22) reported that the combination of $C$. infirmo-miniatus and modified atmosphere packaging (MAP) with 2 to $6 \% \mathrm{O}_{2}$ and $1 \% \mathrm{CO}_{2}$ reduced blue mold better than MAP without yeast or treatment with $C$. infirmo-miniatus fol-

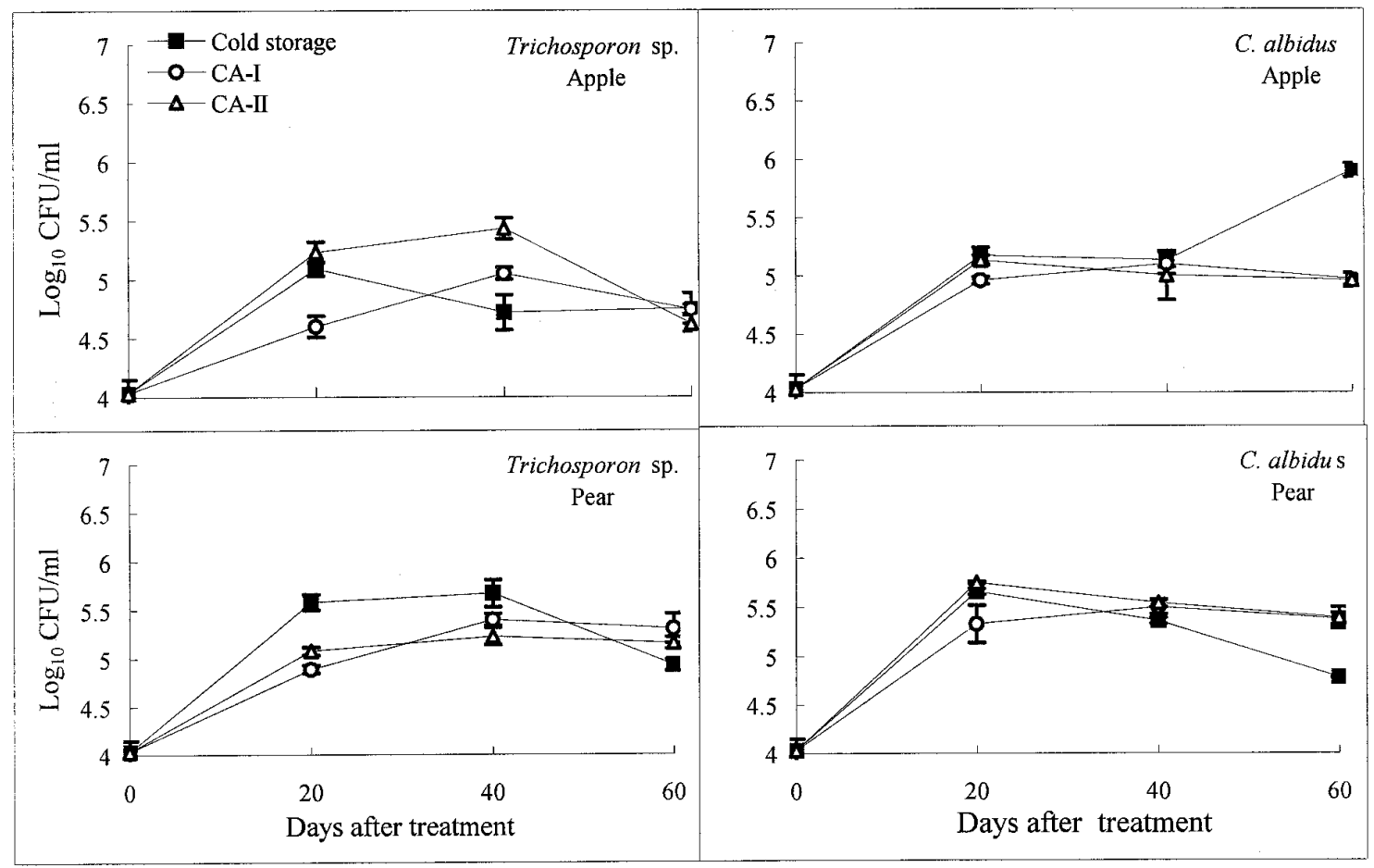

Fig. 6. Population dynamics of Cryptococcus albidus and Trichosporon sp. in wounds of apple and pear fruits incubated at $1^{\circ} \mathrm{C}$ in air and controlled atmospheres. Fruits were wounded and $20 \mu \mathrm{l}$ of suspension at $5 \times 10^{6} \mathrm{CFU} / \mathrm{ml}$ was applied to each wound. The antagonists were recovered by removing the wounded tissue, grinding it in a mortar with $0.05 \mathrm{M}$ phosphate buffer, and plating $0.1 \mathrm{ml}$ of a 10-fold dilution on nutrient yeast dextrose agar (NYDA). There were three replicates per treatment and the test was conducted twice. The data were pooled from two experiments. Bars represent standard errors of the mean. CA-I: $3 \% \mathrm{O}_{2}+3 \% \mathrm{CO}_{2}$; CA-II: $3 \% \mathrm{O}_{2}+8 \% \mathrm{CO}_{2}$.

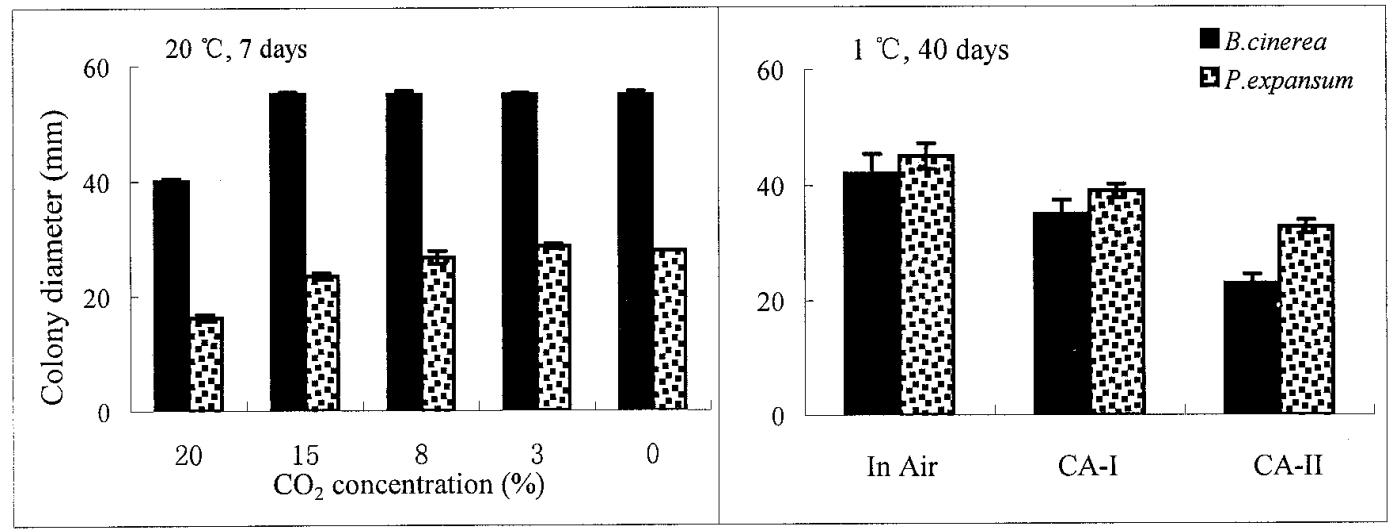

Fig. 7. Growth of Botrytis cinerea and Penicillium expansum in vitro under different storage conditions. Five replications per treatment were used and the experiment was conducted twice. The data were pooled from two experiments. Bars represent standard errors of the mean. $\mathrm{CA}^{\mathrm{I}} \mathrm{I}: 3 \% \mathrm{O}_{2}+3 \% \mathrm{CO}_{2} ; \mathrm{CA}_{-} \mathrm{II}$ : $3 \% \mathrm{O}_{2}+8 \% \mathrm{CO}_{2}$ 
lowed by storage in air. Spotts et al. (28) reported that treatment of sweet cherry with $C$. infirmo-miniatus and storage in MAP $\left(5.1 \% \quad \mathrm{O}_{2}\right.$ and $\left.11.4 \% \quad \mathrm{CO}_{2}\right)$ reduced brown rot incidence by $98.2 \%$. Our results that C. albidus and Trichosporon sp. under CA storage conditions effectively controlled gray mold and blue mold in apples agree with these previous studies. The CA effect may be attributed to a combination of suppression of $B$. cinerea and $P$. expansum and stimulation of the yeasts by the high $\mathrm{CO}_{2}$. Although C. albidus and Trichosporon sp. controlled gray mold and blue mold of apple fruits, neither yeast controlled decay of pear fruits, even in CA. This may be related in part to 'Golden Delicious' apple having a better storability both in cold air storage and under the CA conditions than 'Jingbai' pears (data not shown).

Rapid colonization of wounds by a microbe is important if it is to be an effective antagonist $(23,36,37)$, and there is a direct relationship between the population of antagonist and the biocontrol efficacy $(10,13,16)$. We found that populations of Trichosporon sp. and C. albidus increased rapidly at $25^{\circ} \mathrm{C}$ and then stabilized for the remaining period (Fig. 5), while in cold storage and CA conditions at $1{ }^{\circ} \mathrm{C}$, an initial increase often was found after 20 days (Fig. 6). This result indicated that Trichosporon sp. and C. albidus were well adapted to the wound environment in fruit and have considerable potential as biocontrol agents. The ability of yeasts to multiply rapidly in wounds, and perhaps preemptively utilize available nutrients, may facilitate biocontrol by nutrient competition (36).

In addition, an effective antagonist must be compatible with routine postharvest treatments (37). Our previous study showed that $C$. albidus and Trichosporon sp. are compatible with several postharvest practices, including fungicide and $\mathrm{Ca}^{2+}$ treatment, making feasible an integrated control strategy under commercial conditions (11,34). This approach not only makes it possible to reduce fungicide concentrations while maintaining adequate decay control, but also ensures a reduction of the chemical residue on the fruit. However, further research is needed to determine the best concentrations of $\mathrm{O}_{2}$ and $\mathrm{CO}_{2}$, both for the yeasts and the fruits, and the mechanisms of biocontrol by $C$. albidus and Trichosporon sp.

\section{ACKNOWLEDGMENTS}

This work was supported by the grants from National Natural Science Foundation of China (NNSF-30170663) and the Chinese Academy of Sciences.

\section{LITERATURE CITED}

1. Bertolini, P., and Tian, S. P. 1996. Low temperature biology and pathogenicity of Penicillium hirsutum on garlic in storage. Postharvest Biol. Technol. 7:83-89.

2. Bertolini, P., and Tian, S. P. 1997. Effect of temperature of production of Botrytis allii conidia on their pathogenicity to harvested white onion bulbs. Plant Pathol. 46:432-438.

3. Chalutz, E., and Wilson, C. L. 1990. Postharvest biocontrol of green and blue mold and sour rot of citrus fruit by Debaryomyces hansenii. Plant Dis. 74:134-137.

4. Chand-Goyal, T., and Spotts, R. A. 1996. Control of postharvest pear diseases using natural saprophytic yeast colonists and their integration with low dosage of thiabendazole. Postharvest Biol. Technol. 7:51-64.

5. Chand-Goyal, T., and Spotts, R. A. 1996. Postharvest biological control of blue mold of apple and brown rot of sweet cherry by natural saprophytic yeasts alone or in combination with low doses of fungicides. Biol. Control 6:253-259.

6. Chand-Goyal, T., and Spotts, R. A. 1997. Biological control of postharvest diseases of apple and pear under semi-commercial and commercial conditions using three saprophytic yeasts. Biol. Control 10:199-206.

7. Conway, W. S., Janisiewicz, W. J., Klein, J. D., and Sams, C. E. 1999. Strategy for combining heat treatment, calcium infiltration, and biological control to reduce postharvest decay of 'Gala' Apples. HortScience 34:700704.

8. El-Ghaouth, A., Smilanick, J. L., and Wilson, C. L. 2000. Enhancement of the performance of Candida saitoana by the addition of glycolchitosan for the control of postharvest decay of apple and citrus fruit. Postharvest Biol. Technol. 19:103-110.

9. El-Ghaouth, A., and Wilson, C. 1995. Biologically-based technologies for the control of postharvest diseases. Postharvest News Inform. 6:5-11.

10. Fan, Q., and Tian, S. P. 2000. Postharvest biological control of Rhizopus rot of nectarine fruits by Pichia membranefaciens. Plant Dis. 84:1212-1216.

11. Fan, Q., and Tian, S. P. 2001. Postharvest biological control of grey mold and blue mold on apple by Cryptococcus albidus (Saito) Skinner. Postharvest Biol. Technol. 21:341353.

12. Fan, Q., Tian, S. P., Li, Y. X., Xu, Y., and Wang, Y. 2000. Biological control of postharvest brown rot in peach and nectarine fruits by Bacillus subtilis (B-912). Acta Bot. Sinica 42:1137-1143.

13. Fan, Q., Tian, S. P., Xu, Y., Wang, Y., and Jiang, A. L. 2000. Biological control of Rhizopus rot of peach fruits by Candida guilliermondii. Acta Bot. Sinica 42:10331038.

14. Filonow, A. B. 1998. Role of competition for sugars by yeasts in the biocontrol of gray mold of apple. Biocontrol Sci. Technol. 8:243-256.

15. Holmes, G. J., and Eckert, J. W. 1999. Sensitivity of Penicillium digitatum and P. italicum to postharvest citrus fungicides in California. Phytopathology 89:716-721.

16. Janisiewicz, W. J. 1988. Biocontrol of postharvest diseases of apples with antagonist mixtures. Phytopathology 78:194-198.

17. Janisiewicz, W. J., and Jeffers, S. N. 1997. Efficacy of commercial formulation of two biofungicides for control of blue mold and gray mold of apples in cold storage. Crop Prot. 16:629-633

18. Janisiewicz, W. J., and Marchi, A. 1992. Control of storage rots on various pear cultivars with a saprophytic strain of Pseudomonas syringae. Plant Dis. 76:555-560.

19. Lima, G., De Curtis, F., Castoria, R., and De Cicco, V. 1998. Activity of the yeasts Cryptococcus laurentii and Rhodotorula glutinis against post-harvest rots on different fruits. Biocontrol Sci. Technol. 8:257-267.

20. McLaughlin, R. J., Wilson, C. L., Droby, S., Ben-Arie, R., and Chalutz, E. 1992. Biologi- cal control of postharvest diseases of grape, peach, and apple with yeasts Kloeckera apiculata and Candida guilliermondii. Plant Dis. 76:470-473.

21. Mercier, J., and Wilson, C. L. 1994. Colonization of apple wounds by naturally occurring microflora and introduced Candida oleophila and their effect on infection by Botrytis cinerea during storage. Biol. Control 4:138-144.

22. Miller, M., and Sugar, D. 1997. Modified atmosphere packaging and its applications in storage, decay control, and marketing pears. Pages 277-284 in: Proc. Int. Controlled Atmosphere Res. Conf. E. J. Mitcham, ed. University of California, Davis.

23. O'Brien, R. D., and Lindow, S. E. 1989 Effect of plant species and environmental conditions on epiphytic population sizes of Pseudomonas syringae and other bacteria. Phytopathology 79:619-627.

24. Reyes, A. A. 1988. Suppression of Sclerotinia sclerotiorum and watery soft rot of celery by controlled atmosphere storage. Plant Dis. 72:790-792.

25. Roberts, R. G. 1990. Postharvest biological control of gray mold of apple by Cryptococcus laurentii. Phytopathology 80:526-530.

26. Sitton, J. W., and Patterson, M. E. 1992. Effect of high-carbon dioxide and low-oxygen controlled atmospheres on postharvest decays of apples. Plant Dis. 76:992-995.

27. Sommer, N. F. 1985. Role of controlled environments in suppression of postharvest diseases. Can. J. Plant Pathol. 7:331-336.

28. Spotts, R. A., Cervantes, L. A., Facteau, T. J., and Chand-Goyal, T. 1998. Control of brown rot and blue mold of sweet cherry with preharvest iprodione, postharvest Cryptococcus infirmo-miniatus, and modified atmosphere packaging. Plant Dis. 82:1158-1160.

29. Tian, S. P. 2001. Effects of low temperature on mycelial growth and spore germination of Botrytis cinerea in vitro and on its infectivity to stored chicory. Acta Phytopathol. Sinica 31:56-62.

30. Tian, S. P., and Bertolini, P. 1995. Effects of low temperature on mycelial growth and spore germination of Botrytis allii in culture and on its pathogenicity to stored garlic bulbs. Plant Pathol. 44:1008-1015.

31. Tian, S. P., and Bertolini, P. 1996. Changes in conidial morphology and germinability of $\mathrm{Bo}$ trytis allii and Penicillium hirsutum in response to low temperature incubation. Mycol. Res. 100:591-596.

32. Tian, S. P., and Bertolini, P. 1999. Influence of conidia production temperature on morphology, germinability and infectivity of Monilinia laxa in stored nectarine. J. Phytopathol. 147:635-641.

33. Tian, S. P., and Fan, Q. 2000. Biological technologies for controlling postharvest diseases of fruits and vegetables. Chin. Bull. Bot. 17:193-203.

34. Tian, S. P., Fan, Q., Xu, Y., and Wang, Y. 2001. Effects of Trichosporon sp. in combination with calcium and fungicide on biocontrol of postharvest diseases in apple fruits. Acta Bot. Sinica 43:523-530.

35. Tian, S. P., Fan, Q., Xu, Y., Wang, Y., and Jiang, A. L. 2001. Evaluation of the use of high $\mathrm{CO}_{2}$ concentrations and cold storage to control of Monilinia fructicola on sweet cherries. Postharvest Biol. Technol. 21:53-60.

36. Wilson, C. L., and Wisniewki, M. E. 1989. Biological control of postharvest diseases of fruits and vegetables: An emerging technology. Annu. Rev. Phytopathol. 27:425-441.

37. Wilson, C. L., Wisniewski, M. E., Droby, S., and Chalutz, E. 1993. A selection strategy for microbial antagonists to control postharvest diseases of fruits and vegetables. Sci. Hortic. 53:183-189. 